\title{
ETHICAL ISSUES IN DISCLOSING DIAGNOSTIC AND PROGNOSTIC INFORMATION TO CANCER PATIENTS
}

\author{
Vvedenskaya EV1,2凶, Lepkova NV¹, Egorova AV1 \\ ${ }_{1}$ Pirogov Russian National Research Medical University, Moscow, Russia \\ 2 INION RAS Moscow, Russia
}

\begin{abstract}
The article talks about the ethical dilemmas of diagnostic and prognostic disclosure in oncology. Below, we discuss the principles of diagnostic and prognostic disclosure to curable and terminally ill patients proposed by Soviet medical deontology. Despite its evolution, the principle of benevolent deception applied to incurable patients in the USSR still persists into the present. The article discusses the cons and pros of withholding the diagnosis from terminally ill patients and the Russian legislation on the patient's rights. The article places a special focus on the strategy of disclosing an unfavorable diagnosis to a cancer patient adopted in Russian oncology.
\end{abstract}

Keywords: informing, informed consent, oncology, deontology, "benevolent deception", diagnosis

Author contribution: Vvedenskaya EV — studying literature, writing an article; Lepkova NV, Egorova AV — contribution to the concept and structure of the article, editing

$\triangle$ Correspondence should be addressed: Helena V. Vvedenskaya

Ostrovityanova st. 1, Moscow; vvedenskaya.elena@gmail.com

Received: 12.02.2021 Accepted: 26.03.2021 Published online: 31.03.2021

DOI: $10.24075 /$ medet.2021.005

\section{ЭТИЧЕСКИЕ ПРОБЛЕМЫ ИНФОРМИРОВАНИЯ ОНКОЛОГИЧЕСКИХ ПАЦИЕНТОВ В РОССИИ}

\author{
Е. В. Введенская $1,2 凶$, Н. В. Лепкова ${ }^{1}$, А. В. Егорова ${ }^{1}$ \\ ${ }^{1}$ Российский национальный исследовательский медицинский университет имени Н. И. Пирогова, Москва, Россия \\ 2 ИНИОН РАН Москва, Россия
}

Статья посвящена этическим проблемам информирования пациентов в онкологии. Анализируются принципы инсормирования онкологических больных, в том числе инкурабельных, разработанные в советской медицинской деонтологии. Отмечается, что принцип «доброжелательного обмана», принятый в отношении инкурабельных больных в СССР, претерпевает эволюцию в отечественной онкологии, однако не преодолен в полной мере к настоящему времени. Рассматриваются аргументы «за» и «против» сокрытия врачами онкологического диагноза для неизлечимых больных, а также требования российского законодательства в отношении соблюдения прав пациента. Особое внимание уделено информированию пациента и тактике сообщения неблагоприятного диагноза в современной российской онкологии.

Ключевые слова: информирование, информированное согласие, онкология, деонтология, “доброжелательный обман», диагноз

Вклад авторов: Введенская Е. В. - изучение литературы, написание статьи; Лепкова Н. В., Егорова А. В. - вклад в концепцию и структуру статьи, редактирование.

$\bigotimes$ Для корреспонденции: Елена Валерьевна Введенская,

ул. Островитянова, д. 1, г. Москва, 117997; vvedenskaya.elena@gmail.com

Статья получена: 12.02.2021 Статья принята к печати: 26.03.2021 Опубликована онлайн: 31.03.2021

DOI: $10.24075 /$ medet.2021.005

For an oncologist, the ability to establish rapport and achieve cohesion with a cancer patient is just as essential as the high level of competence. According to eminent Soviet oncologists, "any disruption of this cohesion can have a tragic effect on the patient's life" [1]. One of the most complex ethical dilemmas faced by oncologists is whether to withhold or disclose the diagnosis, prognosis and difficulties associated with treatment, including surgical interventions, to a cancer patient.

\section{Deontological ethics in Soviet medicine and full disclosure in oncology}

Prognostic and diagnostic disclosure in oncology was extensively debated in the Soviet medical deontological literature. One of the key works on this problem published during the Soviet period was a scholarly monograph Questions of surgical deontology by Nikolai N. Petrov, the member of the Soviet Academy of Medical Sciences, which enunciated the basic deontological principles of Soviet surgery. "A patient is not a faceless case but an individual with complex feelings", Petrov wrote; therefore, physicians "should look for a treatment suitable for the patient instead of looking for a patient suitable for a therapeutic intervention" [2]. Petrov argued the need for a personalized approach to treatment. The essence of this approach was articulated in 4 Preoperative Conclusions: 1 motivated diagnosis; 2 - indications for surgery; 3 - surgery plan; 4 - anesthesia. Obviously, the conclusions had to be drawn based on the meticulous study of the patient's personality and in his/her best interest. In other words, a few decades before the science of bioethics emerged, Petrov had defined its fundamental principle: respect for patient autonomy. The Soviet surgeon recommended that physicians should discuss the available treatment options with the patient and let the patient decide whether the proposed surgical intervention was worth-while. Petrov held the opinion that "by adopting a tactful and friendly attitude to the patient, the surgeon can engage them into decision making about surgery" [2]. However, the "respect for patient autonomy" rule did not apply to incurable patients, who were taken care of in a paternalistic fashion.

According to the ethics of the Soviet medical practice, physicians were expected to have a lot of consideration for the mental health of cancer patients and avoid using words like cancer, sarcoma or metastasis in their presence so as to reduce the probability of reactive psychiatric disorders, distress and hysterical fits. It was recommended that the diagnosis should not be disclosed to the incurable patient and the patient should be given the impression that he/she was receiving some therapy, i.e. the patient was told they had "gastric ulcer" or a 
"tumor" and was prescribed unrelated long-term therapy [2]. When dwelling on the communication between the doctor and the patient, Petrov said that although it is impossible to predict how the conversation with the patient might go, an experienced physician with good knowledge of deontology can find the right words, imagining that their patient is "someone special they seek to give relief to by all means, but not a faceless uninteresting case" [2].

In Petrov's monograph written a few years before the Nuremberg Code (1947), there is a chapter proposing the concept of informed consent. The bioethicist E.P. MikhalovskaKarlova observed that "requirements formulated by Petrov almost mirrored the content of informed consent as we know it today" [3]. Petrov believed that the doctor should talk to the patient about the diagnosis and surgery in simple unintimidating terms, providing some prognostic details and information about mandatory prophylaxis. If a surgical intervention is necessary, the surgeon must insist on it and yet mention a few possible risks, like the risk of infection or injury; however, the surgeon must emphasize that the risks far outweigh the benefits of surgery. Importantly, Petrov recognized the need for full disclosure only in cases when there was no other way to obtain informed consent from the patient.

According to Petrov, if a patient is inoperable or surgery is associated with significant risks, the surgeon should explain to the patient in plain language that surgery may be fatal or lead to grave complications. Besides, the patient should be informed of preoperative preparations and anesthesia in order to avoid "counterproductive debate or rude altercations in the operating room that discredit surgery as such" [2].

Rules of communication between the doctor and the terminally ill patient formulated by Petrov are based on the principle of benevolent deception, which prescribes to conceal a true terminal diagnosis and tell the patient they have something much less terrifying than cancer. "Not only so-called uninitiated persons but also distinguished surgeons, when they take seriously ill and become patients themselves, believe a skillful well-intentioned lie, find comfort in it and die peacefully with it", Petrov wrote [2]. Alternatively, the doctor may tell the patient the diagnosis is inconclusive and thus let the patient find comfort in doubt. Petrov believed that physicians should maintain the illusion of recovery in an incurable patient for the good of the patient; therefore, the doctor does not have the moral right to tell the patient that their cancer is inoperable and that there is no cure: "It is not advisable to tell a terminally ill patient that he/she is inoperable; instead, the physician should plant a thought in the patient that surgery is not necessary at this stage. Under no circumstances should the physician tell the patient that the medical science has not yet come up with a treatment for their disease and thus deny the patient any treatment. This kills all hope and aggravates suffering" [2].

Deontological principles formulated by Petrov were expanded upon by another member of the Soviet Academy of Medical Sciences, Nikolai N. Blokhin, in his work "Deontology in oncology" (1977). Blokhin addressed a wide range of ethical issues, including the significance of direct communication between the doctor and the patient, the need for full disclosure to patients that can potentially be cured and their close relatives, and the importance of eradicating fringe medicine to which the patient may turn to and thus lose precious time.

Following the ancient principle "first, do no harm", which is ascribed to Hippocrates and prompts the doctor to shield the patient's psyche from a blow, Blokhin echoed Petrov's words by saying: "A doctor must not tell a terminally ill patient the whole truth, although there may be other options in other cases" because "the doctor cannot predict what may happen after the patient hears the truth" [4].

Benevolent deception of incurable patients: evolution of opinions in Russian oncology

Relying on the idea of a kind and caring attitude toward a patient, Petrov and Blokhin advocated the principle of benevolent deception in diagnostic and prognostic disclosure to patients with terminal cancer. In the Soviet time, withholding a dreadful diagnosis was part of adherence to the "patient confidentiality" rule. During the first State-wide USSR Conference on Medical Deontology (1969), Prof. F.V. Gulyaev spoke about the commitment of Soviet physicians to this principle: "We abide by the rule of concealing a cancer diagnosis from the patient, although it is becoming increasingly difficult due to the spread of non-academic medical journals" [5].

The principle of withholding diagnostic and prognostic information from an incurable patient is predicated on the following assumptions. Full diagnostic and prognostic disclosure to a terminally ill patient contradicts the injunction "first, do no harm". It is not rare that a patient, unable to cope with the truth, commits suicide after finding out about their diagnosis. There is a belief that a false benign diagnosis mitigates the course of the disease. Besides, there are diagnostic and prognostic errors. Insisting on the truth, the patient usually wants to hear something optimistic. Telling a terminally ill patient the whole truth suggests professional inadequacy. Russian laws and the Declaration of Lisbon on the Rights of the Patient declare the patient's right not to know.

At the same time, truth is a manifestation of respect for a human being, human dignity and autonomy, i.e. the right for self-determination. Truth is the starting point for making choices about treatment, refusing treatment and dealing with other challenges in life. It is currently held that lying to the patient about the positive outcome is immoral. According to the psychologist A.V. Gnezdilov, such deception does harm to the patient because it is inconsistent with the actual dynamics of the disease. There are patients who realize or intuitively feel that they are being lied to and suffer from the lie even more as the disease progresses. This was brilliantly described by Tolstoy in his novella The death of Ivan Ilyich: "What tormented Ivan Ilyich most was the deception, the lie, which for some reason they all accepted, that he was not dying but was simply ill, and he only need keep quiet and undergo a treatment and then something very good would result. He however knew that do what they would nothing would come of it, only still more agonizing suffering and death. This deception tortured him their not wishing to admit what they all knew and what he knew, but wanting to lie to him concerning his terrible condition, and wishing and forcing him to participate in that lie. Those lies lies enacted over him on the eve of his death and destined to degrade this awful, solemn act to the level of their visitings, their curtains, their sturgeon for dinner-were a terrible agony for Ivan llyich... This falsity around him and within him did more than anything else to poison his last days" [6].

The incurability of some cancer patients brings up the question: "Could it be that by defending their privilege to lie to terminally ill patients some oncologists reveal their own fear of death and therefore cannot maintain their professional attitude with dying patients?". Prof. J. Klaesi once made a fair observation that the ultimate mission of the doctor begins when chances of curing the patient have run out. Expanding upon Klaesi's thought, V.Frankl, a Nazi camp survivor who had witnessed the suffering of those sentenced to death, wrote that the doctor should care for the patient's soul and help them endure their ordeals. "It is not about recovering the ability to 
work or enjoy life, for these abilities are irreversibly lost, but about developing the ability to endure suffering" [7].

In the West, the ethical dilemma of diagnostic disclosure to a cancer patient has been almost completely solved. Oncologists are obliged by the law to tell the truth to their patients, otherwise the patient may sue the healthcare provider for withholding information. The first legal document protecting the rights of the patient was the Patient's Bill of Rights adopted by the American Hospital Association in 1973. One of the key provisions of the Bill was the patient's right for "relevant, current, and understandable information about his or her diagnosis, treatment, and prognosis" [8]. However, Declaration of Lisbon adopted in 1981 ruled that "exceptionally, information may be withheld from the patient when there is good reason to believe that this information would create a serious hazard to his/her life or health" [9]. In 1994, the European Consultation on the Rights of Patients adopted the Declaration on the Promotion of Patients' Rights in Europe. This document declared the patient's right for exhaustive information about their health, including information about possible risks and advantages of alternative treatment options [10].

In the 1990s, full diagnostic and prognostic disclosure was advocated by Nikolai N. Trapeznikov, director of Blokhin National Medical Research Center of Oncology. Owing to scientific and technological advances in cancer treatment, the word "cancer" was no longer perceived as a synonym of painful death. The Constitution of Russia adopted in 1992 now guaranteed and protected human rights, which, in the context of public health, meant protection of patients' rights.

Article 41 of the current Constitution proclaims the right for health protection and medical care, including protection against adverse yet inevitable consequences of treatment. This obliges the doctor to inform the patient about all possible side effects of treatment, its effectiveness, the right to refuse therapy, and disease progression in the absence of treatment [11].

In Russia, the doctor-patient relationship is regulated by the Federal law № 323 On the fundamental principles of public health protection № 323 passed in 2011. Article 19 of this Law guarantees that the patient has the right to obtain information about his/her rights, responsibilities, and health condition and to choose a representative to receive information about the patient's health on his/her behalf [12].

Article 20 prohibits performing any healthcare intervention on the patient in the absence of informed consent obtained from the patient or their legal representative. Informed consent is based on the patient's understanding of information provided to the patient or their legal representative by the healthcare provider about treatment goals, methods, risks, consequences, options and outcomes [12].

However, contrary to legal requirements, diagnostic and prognostic disclosure is not always practiced as it should be. Disclosure is still a moral dilemma for the doctor who is the one to decide whether to tell or not to tell the whole truth to a terminally ill patient. Oncologists have to consider the physical, mental, and emotional states of their patients and determine if the later are ready to hear the truth. According to Article 22 of the Federal Law № 323, information about the patient's health cannot be delivered to the patient against their will [12]. The existing solution to the ethical dilemma of full disclosure is ambiguous: the patient has the right to know and the right to refuse information regarding their health. Not every patient wants to know about their diagnosis, and so keeping the patient in the best possible health, both physical and mental, should be the physician's top priority.

\section{Diagnostic and prognostic disclosure and communication strategies in contemporary Russian oncology}

The conversation between the doctor and the patient is a crucial moment. The more experienced the doctor, the less the patient struggles with understanding and accepting the diagnosis and the more confidence he/she has in the positive outcome. According to the Federal Law No.323, every patient has the right for full and understandable information about their diagnosis, results of diagnostic tests, treatment options, risks and prognosis. This information is provided by the attending physician or another healthcare worker involved in diagnosing and treating the patient. If the patient is underage or legally incapacitated, the physician discloses diagnostic and prognostic information to their legal representative.

Because Soviet deontology had been following its own idiosyncratic path and due to the specific features of the Russian mentality and the way of life, Russian oncologists take a very subtle, personalized approach to breaking bad news to the patient. According to Irina M. Starovoytova of the Russian Medical Academy of Continuous Professional Education, a Russian oncologist "has to undertake the grueling task of conveying the diagnosis in a way that will give the patient hope, mobilize them for radical treatment and yet be truthful but not blunt" [13].

Patients respond to bad news differently, depending on their higher nervous activity type [14]. In their practice, Russian oncologists use the classification of personality types first proposed by Hippocrates (the $5^{\text {th }}$ century $\mathrm{BC}$ ) and later expanded upon by Galen (the $2^{\text {nd }}$ century $\mathrm{BC}$ ). In the 20th century, the outstanding Soviet scientist Ivan Pavlov proved that the higher nervous activity type is the biological basis of temperament [15]. According to the temperamentbased classification of personality types, a sanguine person is characterized by frequent mood swings, short duration of impressions, and fast response to the environment; this personality type easily reconciles with failures and troubles. A phlegmatic individual is usually composed, persistent, steadfast, calm and does not show their emotions and feelings much. Sanguine and phlegmatic individuals are not difficult patients. They take their diagnosis calmly and forge ahead to recovery if their doctor maintains good contact with them and informs them of all diagnostic and therapeutic steps that need to be taken.

Choleric and melancholic individuals are more difficult patients. A choleric person is quick, impulsive, passionate, volatile, easily tired, and has frequent mood swings and emotional outburst. When conversing with a choleric patient, the doctor should be very attentive, calm and level-headed. Such patients need to be repeatedly reminded of the importance of diagnostic and therapeutic manipulations.

A melancholic individual is very vulnerable, anxious, and weakly responds to the environment. This personality type cannot hold back their asthenic feelings by willpower alone and is very sensitive. The physician should not be straightforward about the diagnosis with a melancholic patient; it is advisable to arrange for a candid and intimate conversation with the patient and then calmly and confidently tell the patient that in order to recover he/she needs therapy. It is important to show tact and patience, to use synonyms instead of direct medical terms when talking about the disease. The primary goal of the conversation is to help the patient accept the diagnosis and motivate them to undergo treatment despite the hardships associated with it. The more positive attitude the patient has, the more effectively their therapy will work. But if the patient 
refuses to know the diagnosis, the doctor has no right to force this information upon them. Instead, the diagnosis should be tactfully communicated to the patient's representatives.

Understanding what the patient wants and being ready to help them digest the bad news is conducive to a successful conversation. The doctor should listen to and hear the patient. Gnezdilov writes: "When engaging in a dialogue with the patient, the doctor should be the listener and give the patient the opportunity to take an active lead. Sometimes the patient simply needs to vent their emotion but one should not forget that the patient always watches closely the doctor's response to it" [16].

It is important to give information to the patient in small chunks. This will help the patient get ready for hearing the truth in its entirety. A sensitive physician will know when the time is right for full disclosure. According to Gnezdilov, every successive conversation will be more open and detailed. He writes: "For example, a cancer patient is initially in blissful ignorance; so, the physician should start by explaining them what a neoplasm is; in the next conversation the doctor can bring up the term tumor, then a malignant tumor, then cancer and metastasis, and so on" [16].

Another thing to consider when communicating with a patient is the cycle of acceptance. It consists of 5 stages identified by the Swiss-American psychiatrist Elisabeth KüblerRoss (1969). There is no particular deadline for any of these stages [17]. They can be briefly described as follows:

Stage 1: shock or denial. At first, the patient cannot grasp the reality of what has happened. At this stage, the patient should not be left on his own. The physician should explain that the diagnosis is not a death sentence. Reassurance and emotional support should be provided. Often, the shock is followed by panic and overwhelming fear. To cope with the fear, the patient often goes in denial, which is not a positive sign because disbelief delays treatment.

Stage 2: anger. On the one hand, anger is a normal response to a life crisis; on the other hand, it may be destructive and dangerous for the patient.

Stage 3: bargaining. At this stage, the patient tries to come to terms with the situation by striking a deal with god or himself/ herself.

Stage 4: depression. Almost all patients experience depression to a greater or lesser degree because the disease interferes with their plans for the future. The hardest part for both the doctor and the patient is when the patient gets stuck in depression. The doctor should find the right words to convince the patient that their plans may still be workable and advances in cancer treatment may help them fulfill their hopes.

Stage 5: acceptance and reassessment. Accepting a grave diagnosis is not the same thing as putting up with it. Acceptance implies understanding. A patient who has accepted their diagnosis and reassessed their priorities will agree to treatment, take it with dignity, and possibly become a role model for others.

A patient can quickly go through any of these stages, or skip it, or even get stuck in it; the most important thing is to forge ahead, reach acceptance and initiate therapy without delay.

Oncologists communicate with their patients as the later go through the cycle of acceptance and various diagnostic and therapeutic procedures. The doctor should pay attention to all nuances of the patient's physical and emotional state and their response to the information about their diagnosis, treatment and prognosis. The knowledge of psycho-oncology techniques might be invaluable in managing and rehabilitating a cancer patient [18]

\section{References}

1. Chissov VI, Gricman JuJa, Shubin BM. Deontologija v prakticheskoj onkologii/ Deontologija $\vee$ medicine: $v 2$ t. T.2. Chastnaja deontologija. Petrovskii BV, editor. M.: Medicina; 1988; 103 s. Russian.

2. Petrov NN. Voprosy hirurgicheskoj deontologii. L.: GIDUV; 1945 60 s. Russian.

3. Mihalovska-Karlova EP. Formirovanie biojeticheskih predstavleni $\checkmark$ hirurgicheskoj deontologii NN Petrova. Bjulleten' Nacional'nogo nauchno-issledovatel'skogo instituta obshhestvennogo zdorov'ja imeni NA Semashko. 2015; (1):124-126. Russian.

4. Blohin NN. Deontologija v onkologii. - M.: Medicina; 1977; $120 \mathrm{~s}$.

5. Jarovinskij MJa. Medicinskaja jetika (biojetika). Stochik AM., editor. M.: OAO «Izdatel'stvo Medicina»; 2006; 196 s. Russian.

6. Tolstoj LN. Smert' Ivana II'icha. Sobranie sochinenij $\vee 12$ t. M.: «Pravda»; 1987; (11): 80 s. Russian.

7. Frankl V. Teorija i terapija nevrozov. Vvedenie $v$ logoterapiju i jekzistencial'nyj analiz. Zaporozh'e: Big-Press; 2012; 32 s. Russian.

8. AHA Patient's Bill of Rights APRA. http: americanpatient.org/

9. Lissabonskaja deklaracija prav pacienta: prin. na 34-j Vsemirnoj medicinskoj assamblee, Lissabon, Portugalija, 1981 g.; dopoln. na 47-j General'noj Assamblee, Bali, Indonezija, 1995. http:// www.e-stomatology.ru/star/info/2010/lissabon_declaration.htm/

10. Deklaracija o politike $v$ oblasti obespechenija prav pacientov $\vee$

Evrope: utv. Evropejskim bjuro VOZ, Amsterdam, 1994. http:// europadonna.by/index. php?option=com_content\&view=article\& $\mathrm{id}=89: 2010-01-23 /$

11. Konstitucija Rossijskoj Federacii. M.: Jeksmo; 2009; 64 s. Russian.

12. Federal'nyj zakon ot 21 nojabrja 2011 g. N 323-FZ «Ob osnovah ohrany zdorov'ja grazhdan v Rossijskoj Federacii». http://base. garant.ru/12191967/ Russian.

13. Starovojtova IM. Jetika i psihologija $v$ onkologii. Materialy $X$ Rossijskogo onkologicheskogo kongressa 21-23 nojabrja 2006 goda, Moskva. https://rosoncoweb.ru/library/congress/ru/10/22. $\mathrm{php} /$ Russian.

14. Gancev SHH. Onkologiya. Uchebnik dlya medicinskih vuzov. M.: Medicinskoe informacionnoe agentstvo; 2006; 159 s.

15. Pavlov IP. Fiziologicheskoe uchenie o tipah nervnoj sistemy, temperamentah tozh, Poln. Sobr. Soch., kn. 2. M-L, 1951; (3): 77-88. Russian.

16. Gnezdilov AV. Psihologiya i psihoterapiya poter'. Posobie po palliativnoj medicine dlya vrachej, psihologov i vsekh interesuyushchihsya problemoj. SPb.: Rech'; 2002; 162 s. Russian.

17. Kyubler-Ross E. O smerti i umiranii. M.: Sofiya; 2001; 320 s.

18. Belyaev AM et al. Onkopsihologiya dlya vrachej-onkologov i medicinskih psihologov. Rukovodstvo. SPb: Lyubavich; 2017; 352 s. Russian.

\section{Литература}

1. Чиссов В. И., Грицман Ю. Я., Шубин Б. М. Деонтология в практической онкологии. Деонтология в медицине: в 2 т.

Т2. Частная деонтология. Петровский Б. В., редактор. М. Медицина; 1988; 103 с. 
2. Петров Н. Н. Вопросы хирургической деонтологии. Л.: ГИДУВ; 1945; 60 c.

3. Михаловска-Карлова Е. П. Формирование биоэтических представлений в хирургической деонтологии Н. Н. Петрова. Бюллетень Национального научно-исследовательского института общественного здоровья имени Н. А. Семашко, 2015; (1):124-126.

4. Блохин Н. Н. Деонтология в онкологии. М.: Медицина; 1977; $120 \mathrm{c}$.

5. Яровинский М. Я. Медицинская этика (биоэтика). Сточик А. М. редактор. М.: ОАО «Издательство Медицина», 2006; 196 с.

6. Толстой Л. Н. Смерть Ивана Ильича. Собрание сочинений в 12 т. М.: «Правда»; 1987; (11): 80

7. Франкл В. Теория и терапия неврозов. Введение в логотерапию и экзистенциальный анализ. Запорожье: БигПресс; 2012; 32 c.

8. AHA Patient's Bill of Rights APRA. http: americanpatient.org/

9. Лиссабонская декларация прав пациента: прин. на 34-й Всемирной медицинской ассамблее, Лиссабон, Португалия, 1981 г.; дополн. на 47-й Генеральной Ассамблее, Бали, Индонезия, 1995 г. http://www.e-stomatology.ru/star/info/2010/ lissabon_declaration.htm /

10. Декларация о политике в области обеспечения прав пациентов в Европе: утв. Европейским бюро ВОЗ, Амстердам, 1994. http://europadonna.by/index. php?option=com_content\& view=article\&id=89:2010-01- 23/

11. Конституция Российской Федерации. М.: Эксмо; 2009; 64 с.

12. Федеральный закон от 21 ноября 2011 г. N 323-Ф3 «Об основах охраны здоровья граждан в Российской Федерации». http://base.garant.ru/12191967/

13. Старовойтова И. М. Этика и психология в онкологии. Материалы X Российского онкологического конгресса 2123 ноября 2006 года, Москва. https://rosoncoweb.ru/library/ congress/ru/10/22.php/

14. Ганцев Ш. Х. Онкология. Учебник для медицинских вузов. М.: Медицинское информационное агентство: 2006; 159 с.

15. Павлов И. П. Физиологическое учение о типах нервной системы, темпераментах тож. Полн. Собр. Соч., кн. 2. М-Л; 1951; (3): 77-88.

16. Гнездилов А. В. Психология и психотерапия потерь. Пособие по паллиатив ᄀной медицине для врачей, психологов и всех интересующихся проблемой. СПб.: Речь; 2002; 162 с.

17. Кюблер-Росс Э. О смерти и умирании. М.: София; 2001; 320 с.

18. Беляев А. М. и др. Онкопсихология для врачей-онкологов и медицинских психологов. Руководство. СПб: Любавич; 2017; 352 c. 